\title{
Simultaneous Saccharification and Fermentation of Corn Cobs to Bio-Ethanol by Co-Culture of Aspergillus Niger and Saccharomyces Cerevisiae
}

\author{
J. Itelima, A. Ogbonna, S. Pandukur, J. Egbere, and A. Salami
}

\begin{abstract}
The production of bio-ethanol from corn is a mature technology that is not likely to see significant reduction in the production costs. Substantial cost reductions may be possible if cellulose based agricultural wastes such as corn cobs are used instead of corn. In this study, corn cobs which are in abundance and do not interfere with food security was subjected to simultaneous saccharification and fermentation process by co-culture of Aspergillus niger and Saccharomyces cerevisiae for 7 days. The corn cobs were sundried, milled into powder using hammer milling and stored at room temperature $\left(25^{\circ} \mathrm{C}\right)$ before use. The growth media used for culturing Aspergilus niger and Saccharomyces cerevisiae inocula were prepared respectively. Parameters such as biomass yield, cell dry weight, reducing sugar concentration, $\mathrm{pH}$ of the fermentation medium and the ethanol yield were determined at 24 hours intervals. The results of the study revealed that the yeast and mould biomass yield obtained from the corn cobs on the $7^{\text {th }}$ day was 0.59 (OD), while the microbial cell dry weight obtained on the same day was $0.88 \mathrm{mg} / \mathrm{cm}^{3}$. The substrate was hydrolyzed to produce $0.63 \mathrm{mg} / \mathrm{cm}^{3}$ reducing sugar concentrations. The $\mathrm{pH}$ values of the fermentation medium varied between 3.05 and 7.58. Optimal ethanol yield of 10.08v/v was obtained after 7 days of fermentation. The results of this study suggest that agricultural wastes that contain fermentable sugars can no longer be discarded into our environment, but should be converted to useful products like bio-ethanol.
\end{abstract}

Index Terms-Saccharification, fermentation, corn cobs, bioethanol.

\section{INTRODUCTION}

Lignocelllosic biomass can be utilized to produce ethanol, a promising alternative energy for the limited crude oil [1]. There are mainly two process involved in the conversion hydrolysis of cellulose in the lignocellulosic biomass to produce reducing sugars and fermentation of the sugars to ethanol [2]-[5]. The hydrolysis of cellulose is usually catalysed by cellulase enzymes, and fermentation is carried by yeasts or bacteria. During the enzymatic hydrolysis, cellulose is degraded by the cellulase to reducing sugars that can be fermented by yeast or bacteria to ethanol [1] the optimization of cellulose enzymes and enzymes loading can also improve the hydrolysis. Simultaneous saccharification and fermentation effectively removes glucose, which is an

Manuscript received December 5, 2012; revised February 5, 2013.

J. Itelima and A. Ogbonna are with the Department of Plant Science and Technology.

S. Pandukur is with the Department of Science Laboratory Technology.

J. Egbere is with the Department of Microbiology all of University of Jos Nigeria.

A. Salami is with the University of Jos, Nigeria (e-mail: janetitelima@yahoo.com). inhibitory to cellulose activity, thus increasing the yield and rate of cellulose hydrolysis. The contents of cellulose, hemicellulose and lignin in corn cob are $45 \%, 35 \%$ and $15 \%$ respectively [3], [6]. Lignocellulosic feed stocks such as agricultural wastes have favourable utilization potential for bio-ethanol production because of their quantity and competitive price. The main contributive parameter of bio-ethanol is the cost of the raw material and in order to reduce the overall cost of production corn cob which is abundant and do not interfere with food security was used for this experiment. Apart from the solvent nature of ethanol, it could also serve as a basic raw material for the synthesis of other products. It is also a safer alternative to methyl tertiary butyl ether (MTBE), which is usually added to gasoline in order to achieve a better and healthier combustion [7]. The United States Environmental Protection Agency announced its intentions to regulate MTBE addition to gasoline because of its toxic nature and its possible role in the contamination of community water sources [8]. In view of this, the demand for ethanol could further increase [9]. The objective of this study was therefore to produce ethanol from a cheap commonly available agricultural waste such as corn cob with aid of a co-culture of Aspergillus niger and Saccharomyces cerevisiae.

\section{MATERIALS AND MethodS}

\section{A. Preparation of Corn Cobs for Hydrolysis}

A total of 40 corn cobs weighing 70-120g each were dried in the sun and then pulverized with the aid of a hammer mill. The resultant corn powder was sieved with a fine- mesh sieve. A weight of $45 \mathrm{~g}$ of the resultant maize cob powder was then suspended in $500 \mathrm{ml}$ distilled water in $1000 \mathrm{ml}$ conical flask. The flask with its contents was then autoclaved at $121^{\circ} \mathrm{C}$ at $151 \mathrm{~b}$ pressure for a period of 15 minutes after which it was cooled to room temperature.

\section{B. Preparation of Growth Medium}

A. niger growth medium was prepared by mixing Dmannitol $\quad(50.0 \mathrm{~g}), \quad \mathrm{NaNO}_{2} \quad(2.0 \mathrm{~g}), \quad \mathrm{K}_{2} \mathrm{HPO} \mathrm{H}_{4} \quad(0.35 \mathrm{~g})$, $\begin{array}{llllll}\mathrm{MgSO}_{4} & 7 \mathrm{H}_{2} \mathrm{O} & (0.25 \mathrm{~g}), & \mathrm{FeSO}_{4} .7 \mathrm{H}_{2} \mathrm{O} & (0.001 \mathrm{~g}), & \mathrm{ZnSO}_{4}\end{array}$ $(0.00088 \mathrm{~g}), \mathrm{CuSO}_{4} .5 \mathrm{H}_{2} \mathrm{O}(0.0002 \mathrm{~g}), \mathrm{MnSO}_{4} .4 \mathrm{H}_{2} \mathrm{O}(0.00012 \mathrm{~g})$, $\mathrm{NaMoO}_{4} \cdot 2 \mathrm{H}_{2} \mathrm{O}(0.00005 \mathrm{~g})$, Distilled water $(1000 \mathrm{ml})$. The $\mathrm{pH}$ was adjusted to 4 with $\mathrm{H}_{2} \mathrm{SO}_{4}$ and the whole mixture was then sterilized by autoclaving at $121^{\circ} \mathrm{C}$ at 15 psi for 15 minutes. Main while, Saccharomyces cerevisiae growth medium was prepared using yeast - malt broth at $\mathrm{pH} 5.5$ [10].

\section{Preparation of Inocula and Fermentation Procedure}

A. niger inoculum was prepared in $250 \mathrm{~cm}^{3}$ 
cotton-plugged conical flask containing $100 \mathrm{~cm}^{3}$ of the different substrates growth media. The flasks were sterilized and inoculated with 0.11 (OD) A. niger spores. Each of the flasks was incubated on a shaker with agitation rate of 300 $\mathrm{rpm}$ at $30^{\circ} \mathrm{C}$ for five days. S. cerevisiae inoculum was prepared in the same way as the A. niger inoculum except that yeast malt broth was used. The growth medium was inoculated with 0.08 (OD) yeast cells and incubated for 24 hours. The fermentation medium used for ethanol production was identical to the growth medium as indicated above. Ethanol fermentation was carried out in $500 \mathrm{~cm}^{3}$ conical flasks each containing $300 \mathrm{~cm}^{3}$ of medium. The medium was sterilized and inoculated with $5 \%(\mathrm{v} / \mathrm{v})$ growth media containing A. niger and $S$. cerevisiae and incubated on a shaker with an agitation rate of $300 \mathrm{rpm}$ at $30^{\circ} \mathrm{C}$ for seven days.

\section{Analytical Procedure}

Thirty cubic centimeters $\left(30 \mathrm{~cm}^{3}\right)$ of the sample was collected from the flask at 24 hours interval and $27 \mathrm{~cm}^{3}$ was centrifuged at $400 \mathrm{rpm}$ for 30 minutes to remove the cells. The supernatant fluid was filtered through whatman filter paper No.1 and the filtrate was used for determining ethanol and reducing sugar concentration. The remaining $3 \mathrm{~cm}^{3}$ was used to determine the cell density.

\section{E. Determination of Cell Density}

Three cubic centimeters $\left(3 \mathrm{~cm}^{3}\right)$ of the sample was used to determine the cell density at 690nm using CECILCE 1020 spectrophotometer. The spectrophotometer was blanked with an uninoculated fermentation medium.

\section{F. Determination of Cell Dry Weight}

The residue (cells) obtained after centrifugation was filtered using whatman filter paper No.1, washed with distilled water to remove the residual substrates and dried in the hot air oven at $70^{\circ} \mathrm{C}$. The filter paper was pre-weighed before filtering and reweighing after drying until a constant weighed was obtained. Thus, the cell dry weights were determined as follows: Cell dry weight $=$ weight of filter paper and cell after drying - weight of filter paper only.

\section{G. Qualitative and Quantitative Analysis of Reducing Sugar Present in the Samples}

The qualitative analysis was carried out using Benedict's solution (Amadi et al., 2004), while the quantitative analysis was carried out using 3, 5-dinitrosalicylic acid. The concentration of the reducing sugar present in the samples was determined by adding $1 \mathrm{~cm}^{3}$ of 3,5 - dinitrosalicylic acid to $1 \mathrm{~cm}^{3}$ of each of the samples and boiled for 5 minutes and $10 \mathrm{~cm}^{3}$ distilled water was added. The absorbance of each of sample was determined at 540nm using JENWAY 6400 spectrophotometer. Thus, the concentration values were extrapolated from the glucose standard curve [11].

\section{H. Qualitative and Quantitative Analysis of Ethanol Present in the Distillate}

The filtrates were distilled at $70^{\circ} \mathrm{C}$ using rotary evaporator. The qualitative analysis was carried out using ethanolic acid. Two cubic centimeters of ethanolic acid was added to $1 \mathrm{~cm}^{3}$ of the distillate and heated in the water bath for 5 minutes until characteristics sweet smell of esters was perceived.

Thus, concentrations of the distillates were extrapolated from the density standard curve. Furthermore, the $\mathrm{pH}$, refractive index, and specific gravity values were extrapolated from the standard curves prepared from each parameter since the concentrations of the distillates were known [11].

\section{RESUlts AND DisCUSSION}

\section{A. Biomass Yield and Cell Dry Weight}

The yeast and mould (biomass) yield was obtained by determining the absorbance of the samples at $690 \mathrm{~nm}$ which represented the cell density (Fig. 1). The yeast and mould biomass yield obtained from corn cobs (CC) fermentation medium increased gradually from 0.03 (OD) on the first day to 0.59 (OD) on the seventh day. The microbial cell dry weights obtained increased from $0.47 \mathrm{mg} / \mathrm{cm}^{3}$ on the first day to $0.88 \mathrm{mg} / \mathrm{cm}^{3}$ on the seventh day respectively (Fig. 2).

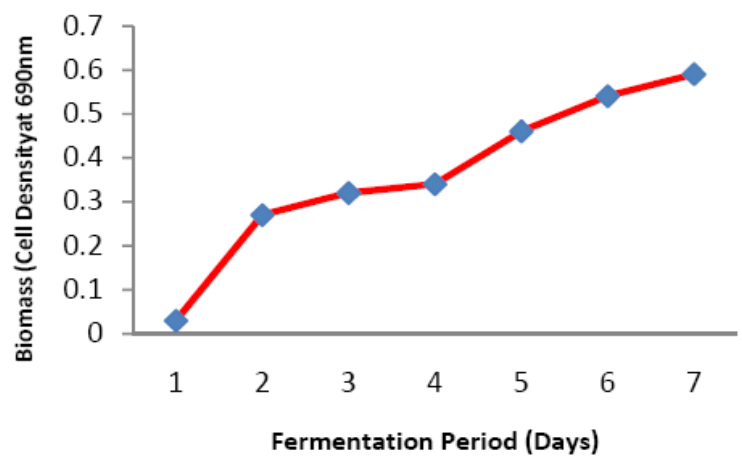

Fig. 1. Yeast and mould yield from corn cobs fermentation medium

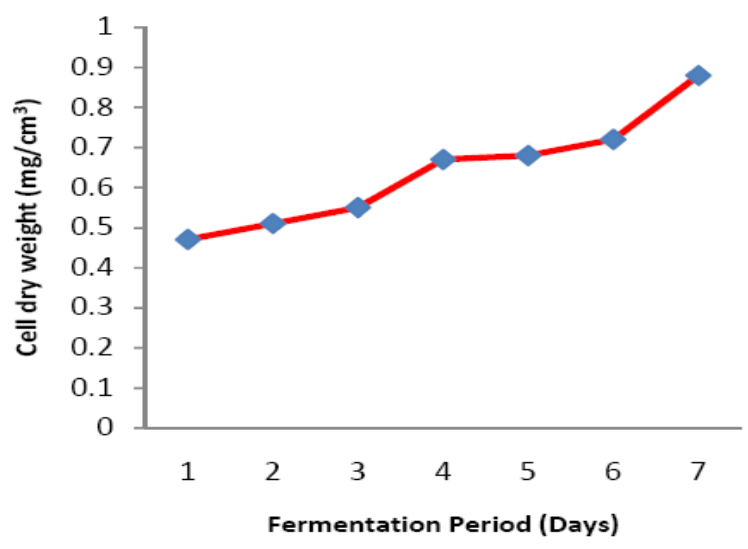

Fig. 2. Microbial cell dry weight obtained from fermentation medium

\section{B. Reducing Sugar Concentration}

The ability of the Aspergillus niger amylase and cellulase to breakdown the corn cobs into reducing sugar was studied. The results are represented in Fig. 3 in terms of the amount of reducing sugars $\left(\mathrm{mg} / \mathrm{cm}^{3}\right)$ produced at 24 hours interval for seven days. Corn cob was rapidly hydrolyzed to produce 0.63 $\mathrm{mg} / \mathrm{cm}^{3}$ reducing sugar and the concentration decreased gradually as the fermentation period increased.

\section{The $p H$ Values of the Fermentation Medium}

The results of the $\mathrm{pH}$ values of the corn cob fermentation medium are shown in (Fig. 4). The values ranged between 3.05 and 7.58. The gradual decrease in $\mathrm{pH}$ as recorded in this study is an indication that acids are accumulated in the fermentation medium during the fermentation process. This 
agrees with the report of [2] that $A$. niger produces organic and by fermentation.

\section{Ethanol Field Obtained from Corn Cobs Fermentation}

The results of the ethanol yield are shown in Fig. 5. Ethanol yield of $1.87 \%(\mathrm{v} / \mathrm{v})$ was obtained on the first day and gradually increased to $10.08 \%(\mathrm{v} / \mathrm{v})$. This result is not comparable to that obtained from ethanol produced from ground corn [12]. Reference [12] showed that $2.69 \mathrm{~kg}$ of ground corn yielded $95 \%$ pure ethanol. Although ground corn gave a higher ethanol yield than corn cobs, the cost of production from corn is one of the most significant factors affecting the economy of ethanol; hence efforts are more concentrated on using cheap raw materials such as agricultural wastes.

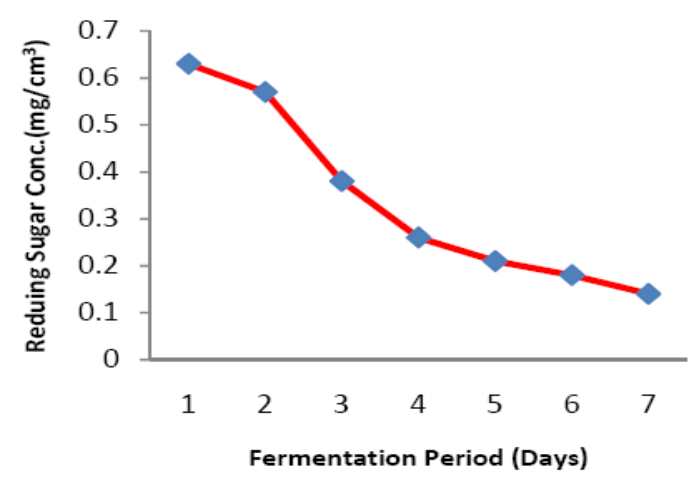

Fig. 3. Reducing Sugar Concentration Obtained from Corn cobs

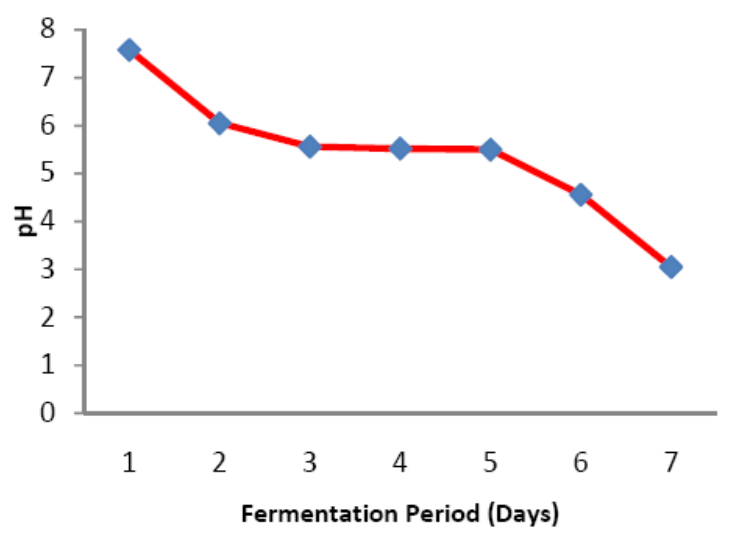

Fig. 4: $\mathrm{pH}$ of Corn Cobs Fermentation Medium

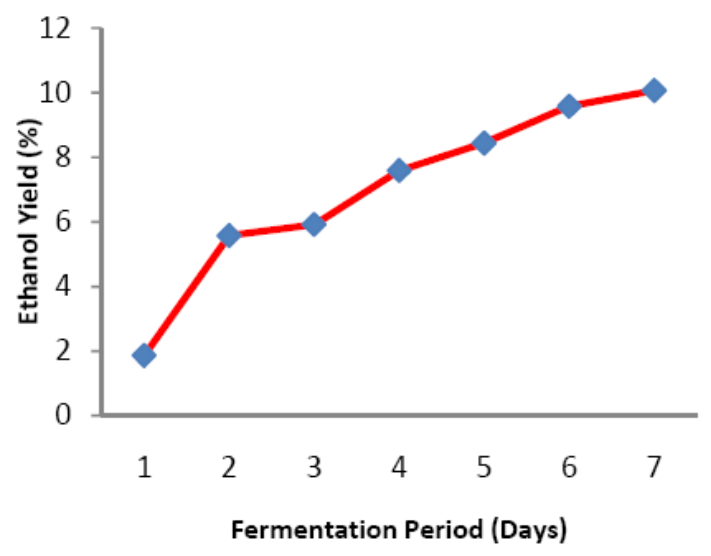

Fig. 5. Ethanol Yield obtained from Corn Cobs

The findings of this study have provided practical examples and gave a broad overview of the current status of ethanol fermentation including biomass resources, microorganisms and technology. Also, the promising prospects of ethanol fermentation are especially highlighted. The significant of the study included are fermentation technology converting agricultural wastes (corn cobs) to ethanol, cellulase enzyme from $A$. niger utilized in the hydrolysis of lignocelluloses materials, immobilization of the microorganism in large quantity, simultaneous and fermentation and sugar conversion into ethanol.

Fuel ethanol production from plant biomass is of great economic and environmental significance [13]. The gradual increase in cell densities suggested that substantially amount of carbon was utilized for ethanol production instead of cell production and this is due to the ability of the yeast $S$. cerevisiae to ferment the sugar to ethanol. The susceptibility of sugars obtained after hydrolysis of corn cobs by $A$. niger to the fermentation activity of $S$. cerevisiae is significantly dependent on the composition of the sugar (Fig. 3). This is because various mixtures of the hexoses (e.g. glucose and mannose) and pentoses (e.g. xylose and arabinose) are released from the hydrolysis of lignocellulosic materials [14]. The fermentation process is significantly dependent on the effectiveness of sugar transporters of $S$. cerevisiae cells at translocating different sugars across the cell membrane. Sugar transporters are membrane bound proteins that take up sugar from the environment and deliver them to the metabolic pathways inside the cell [13]. The result of the present study agrees with the report of [10] that stated that most substrates are utilized for ethanol production in co-culture fermentation (Fig. 5). This study has demonstrated that agricultural lignocellulosic wastes such corn cobs are potential source for the production of bio-ethanol by enzymatic and microbial methods.

The results of the study clearly showed that simultaneous saccharification and fermentation of corn cobs to ethanol by a mixture of starch digesting fungus $A$. niger and a non-starch digesting sugar fermenter $S$. cerevisiae is feasible. The results of this study suggest that agricultural wastes that contain fermentable sugars can no longer be discarded into our environment, but should be converted to useful products like bio-ethanol. Based on this study the following recommendations are made; Biomass availability is the primary factor. A favourable region for bio - ethanol industrial production should have surplus biomass and no problem with food security. Economic factors such as land availability, labour, taxation, utilities, crop processing costs and transportation must be put into consideration otherwise there will be no market for it or no profit for its production even though it is production from renewable resource.

\section{ACKNOWLEDGMENT}

We wish to thank the Department of Plant Science and Technology, Department of Chemistry and the Department of Biochemistry all of University of Jos, Nigeria for providing the chemicals and materials we used during the course of this work.

\section{REFERENCES}

[1] Y. Sun and J. Cheng, "Hydrolysis of Lignocellulosic materials for ethanol production a review," Bioresources Technology, vol. 83. pp. $1-11,2000$. 
[2] A. V. Gusakov, A. P. Sinitsyn, J. A. Manenkova, and O. V. Prostas, "Enzymatic saccharification of industrial and agricultural lignocelllosic wastes," Applied Biochemistry and Biotechnology, vol. 34 , pp. $65,1992$.

[3] S. Reshamwala, B. T. Shawky, and B. E. Dale, "Ethanol production from hydrolysates of AFEX-treated coastal Bermuda grass and switchgrass," Applied Biochemistry and Biotechnology, vol. 51-52, pp. 43-55, 1995 .

[4] A. B. Bjerre, A. B. Olesan, and T. Fernqvist, "Pretreatment of wheat straw using combined wet oxidation and alkaline hydrolysis resulting in convertible cellulose and hemicelluloses," Biotechnology Bioengineering, vol. 49. pp. 568-577, 1996.

[5] S. J. B. Duff and W. D. Murray, "Bioconversion of forest products industry waste cellulosics to fuel ethanol a review," Bioresource Technology, vol. 55, pp. 1-33, 1996.

[6] T. Dewes and E. Hunsche, "Composition and Microbial degradability in the soil of farmyard manure from ecological-managed farm," Biol. Agric. Hortic. vol. 16, pp. 251-268, 1998.

[7] J. D. MacCarthy and M. Tiemann. (1998). MTBE in gasoline: clean air and drinking water issues. CRS report for congress. [Online]. Available:

http://www.epa.gov/otaq/consumer/fuels/mtbe/crs-mtbe.pdf.

[8] SECO. (2006). State Energy Conservation Office. [Online]. Available: http://A:/Ethanol $\% 20$ production $\% 20$

[9] S. O. Jimoh, S. A. Ado, and J. B. Ameh, "Simultaneous saccharification and fermentation of yam peel to Ethanol by Co-culture of Aspergillus niger and Saccharomyces cerevisae," Biol. and J. for the Tropics, vol. 6. pp. 12-10, 2008.
[10] M. M. Abouzei and A. Reddy, "Direct fermentation of potato starch to ethanol by co-culture of aspergillus niger and saccharomyces cerevisiae. J. of Appl," Microbiol. vol. 52. pp. 1055-1059, 1986.

[11] B. A. Amadi, E. N. Agomuo, and C. O. Begbulan, Research Methods in Biochemistry, Suprem Publishers, Owerri, Nigeria, pp. 93-99, 2004.

[12] D. Pimental and T. W. Patzek, "Ethanol production using corn, switch grass and wood; biodiesel production using soybean and sunflower," Natural Resources Research, vol. 14. no. 1, pp. 65-76, 2005.

[13] J. A. Antonius, M. Van, A. Derek, and B. Eleonora, "Alcoholic fermentation of carbon sources in Biomass Hydrolysis by Saccharomyces cerevisiae: Current status," Biomedical and Life Sciences, vol. 90, no. 4, pp. 391-418, April 2006.

[14] Anon. Hydrolysis of lignocellosic materials. [Online]. Available: http://d oegenomestlife.org, 2006.

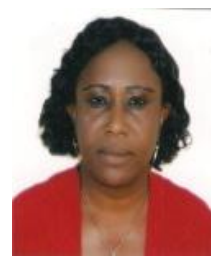

J. Itelima was born on 31, Januray, 1962 in Plateau State, Nigeria. She went to BSc (HONS) Botany in 1988, University of Jos, Nigeria. She applied her MSc Microbiology and Plant Pathology in 1993 in the University of Jos, Nigeria. Her major field of study is applied microbiology and plant pathology. Her current research interest include Bio-fuel, BioFertilizer and Infectious microorganisms, Previous research interest: Research on Medicinal plants Current Job location: Department of Plant Science and Technology, Faculty of Natural Science, University of Jos, Nigeria. 